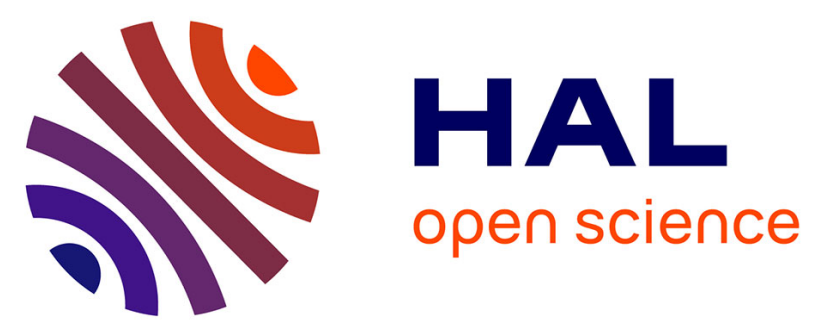

\title{
Synthesis, crystal structure, and electrical and magnetic properties of BaMo6Te6: A novel reduced molybdenum telluride containing infinite chains of trans-face shared Mo6 octahedra
}

Philippe Gall, Thierry Guizouarn, Michel Potel, Patrick Gougeon

\section{To cite this version:}

Philippe Gall, Thierry Guizouarn, Michel Potel, Patrick Gougeon. Synthesis, crystal structure, and electrical and magnetic properties of BaMo6Te6: A novel reduced molybdenum telluride containing infinite chains of trans-face shared Mo6 octahedra. Journal of Solid State Chemistry, 2014, 220, pp.213-216. 10.1016/j.jssc.2014.08.031 . hal-01069306

\section{HAL Id: hal-01069306 https://hal.science/hal-01069306}

Submitted on 8 Oct 2014

HAL is a multi-disciplinary open access archive for the deposit and dissemination of scientific research documents, whether they are published or not. The documents may come from teaching and research institutions in France or abroad, or from public or private research centers.
L'archive ouverte pluridisciplinaire HAL, est destinée au dépôt et à la diffusion de documents scientifiques de niveau recherche, publiés ou non, émanant des établissements d'enseignement et de recherche français ou étrangers, des laboratoires publics ou privés. 
Synthesis, crystal structure, and electrical and magnetic properties of $\mathrm{BaMo}_{6} \mathrm{Te}_{6}:$ a novel reduced molybdenum telluride containing infinite chains of trans-face shared $\mathrm{Mo}_{6}$ octahedra

Philippe Gall, Thierry Guizouarn, Michel Potel and Patrick Gougeon*

Laboratoire de Chimie du Solide et Inorganique Moléculaire, UMR CNRS 6226 - INSA,

Université de Rennes 1, Avenue du Général Leclerc, 35042 Rennes-Cedex, France.

Corresponding Author

Fax: Int. Code + 2232367 99; E-mail: Patrick.Gougeon@univ-rennes1.fr 
Abstract

Powder samples and single crystals of the new ternary compound $\mathrm{BaMo}_{6} \mathrm{Te}_{6}$ were obtained by solid state reaction. The structure was determined by single-crystal X-ray diffraction. $\mathrm{BaMo}_{6} \mathrm{Te}_{6}$ crystallizes in the hexagonal space group $\mathrm{P}_{3} / \mathrm{m}$ (No. 176) with unitcell parameters $\mathrm{a}=9.3941$ (2) $\AA, \mathrm{c}=4.5848$ (1) $\AA$ and $\mathrm{Z}=1$. Full-matrix least-squares refinement on $\mathrm{F}^{2}$ using 452 independent reflections for 17 refinable parameters resulted in $\mathrm{R}_{1}$ $=0.0208$ and $w \mathrm{R}_{2}=0.0539$. The structure consists of one-dimensional infinite chains of transface shared $\mathrm{Mo}_{6}$ octahedra capped by Se atoms. These chains that are running along the $\mathrm{c}$ axis are separated from each other by nine-coordinate $\mathrm{Ba}$ atoms. Resistivity measurements on a single crystal indicated that the $\mathrm{BaMo}_{6} \mathrm{Te}_{6}$ compound is metallic down to $160 \mathrm{~K}$ and semiconductor below. Magnetic susceptibility measurements showed that $\mathrm{BaMo}_{6} \mathrm{Te}_{6}$ is weakly diamagnetic with no anomaly at the metal-semiconductor transition.

Keywords

Reduced molybdenum chalcogenide, infinite molybdenum chains, magnetic susceptibility, resistivity measurement. 


\section{INTRODUCTION}

Since the discovery of the Chevrel phases $\mathrm{MMo}_{6} \mathrm{X}_{8}(\mathrm{M}=$ cation; $\mathrm{X}=\mathrm{S}, \mathrm{Se}, \mathrm{Te})$ [1] containing octahedral $\mathrm{Mo}_{6}$ clusters about forty years ago, a plethora of ternary and quaternary reduced molybdenum chalcogenides containing larger clusters have been synthesized. The latter compounds contain clusters such as $\mathrm{Mo}_{9}, \mathrm{Mo}_{12}, \mathrm{Mo}_{15}, \mathrm{Mo}_{18}, \mathrm{Mo}_{21}, \mathrm{Mo}_{24}, \mathrm{Mo}_{30}$ and $\mathrm{Mo}_{36}$. All of these clusters result from the uniaxial trans-face-condensation of octahedral $\mathrm{Mo}_{6}$ clusters and are present, for example, in the series of compounds $M_{n-2} M_{3 n} X_{3 n+2}(M=R b$, Cs; $\mathrm{X}=\mathrm{S}$, Se or Te; $\mathrm{n}=3,4,5,6,7,8,10$ and 12) [2-12]. The members with even $\mathrm{n}$ crystallize in the rhombohedral trigonal space group R-3 with a structure closely related to the ternary chalcogenides $\mathrm{MMo}_{6} \mathrm{X}_{8}$ and the members with odd $\mathrm{n}$ in the hexagonal space group $\mathrm{P}_{3} / \mathrm{m}$. The final step of the condensation corresponds to the infinite chain of trans-facesharing $\mathrm{Mo}_{6}$ octahedra $\left|\mathrm{Mo}_{6 / 2}\right|_{\infty}^{1}[13,14]$ found in the hexagonal compounds $\mathrm{M}_{2} \mathrm{Mo}_{6} \mathrm{X}_{6}(\mathrm{M}$ $=\mathrm{Na}, \mathrm{K}, \mathrm{Rb}, \mathrm{Cs}, \mathrm{In}, \mathrm{Tl} ; \mathrm{X}=\mathrm{S}, \mathrm{Se}, \mathrm{Te}$ ) and monoclinic one, $\mathrm{AgMo}_{6} \mathrm{Te}_{6}$ [15]. The interest for these compounds lies not only in their fascinating structural aspect but also in their interesting physical properties. Indeed, the sulfides and selenides generally present superconducting or metal-insulator transitions at low temperature. Thus, studies of the normal and superconducting states of both $\mathrm{Cs}_{2} \mathrm{Mo}_{12} \mathrm{Se}_{14}(\mathrm{n}=4)$ and $\mathrm{Rb}_{4} \mathrm{Mo}_{18} \mathrm{Se}_{20}(\mathrm{n}=6)$ by measuring the conductivity and magnetization of single-crystals and powder samples have shown that these compounds can be classified among the "exotic" superconductors [16]. The quasi 1-D superconductor $\mathrm{Tl}_{2} \mathrm{Mo}_{6} \mathrm{Se}_{6}$ presents extreme type II and non-B.C.S. behaviors [17-20]. In addition, the anisotropy of the electronic properties in the latter compound is one of the largest ever observed in a superconductor with the ratio of the conductivities parallel and perpendicular to the infinite chains $\left(\sigma_{/} / \sigma_{\perp}\right)$ of about 1000, and the ratio of the upper critical fields $\left(\mathrm{HC}_{2} / / / \mathrm{HC}_{2} \perp\right)$ of about 26. In contrast, the $\mathrm{M}_{2} \mathrm{Mo}_{6} \mathrm{X}_{6}$ compounds with $\mathrm{M}$ being an element of the group IA present a continuous metal-nonmetal transition between 100 and $150 \mathrm{~K}$ [21]. Recent local density approximation calculations show that in all members of the $\mathrm{M}_{2} \mathrm{Mo}_{6} \mathrm{Se}_{6}$ series, a single 1D helix band crosses the Fermi level. Its in-plane dispersion is reduced by a factor of ten in $\mathrm{Rb}_{2} \mathrm{Mo}_{6} \mathrm{Se}_{6}$ compared with $\mathrm{Tl}_{2} \mathrm{Mo}_{6} \mathrm{Se}_{6}$ and $\mathrm{In}_{2} \mathrm{Mo}_{6} \mathrm{Se}_{6}$ while the out-of-plane dispersion is practically unchanged [22]. This reduction is sufficient to explain the trend from metallic conductivity followed by strongly-coupled superconductivity in $\mathrm{Tl}_{2} \mathrm{Mo}_{6} \mathrm{Se}_{6}$ to a high-temperature metal-insulation transition in $\mathrm{Rb}_{2} \mathrm{Mo}_{6} \mathrm{Se}_{6}$. This insulating 
behaviour is consequence of either a Peierls distortion (Charge Density Wave or CDW), a Spin Density Wave or an Anderson localization. In 1985, Chevrel et al. [23] mentioned the existence of an isomorphous compound, $\mathrm{Ba}_{2} \mathrm{Mo}_{6} \mathrm{Te}_{6}$. However, such a stoichiometry would imply 14 electrons per $\mathrm{Mo}_{3} \mathrm{Te}_{3}$ fragment and thus, which seems improbable, the occupation of antibonding states since the optimal count per $\mathrm{Mo}_{3} \mathrm{Te}_{3}$ is 13 [24]. Thus, we decided to reinvestigate this compound by growing single crystals, in particular. This study has led that the right stoichiometry is in fact $\mathrm{BaMo}_{6} \mathrm{Te}_{6}$. We describe the synthesis, crystal structure, and electrical and magnetic properties of this compound here.

\section{EXPERIMENTAL,}

Synthesis and Crystal Growth

X-ray diffractometrically pure powder of $\mathrm{BaMo}_{6} \mathrm{Te}_{6}$ was prepared from a stoichiometric mixture of $\mathrm{BaTe}, \mathrm{MoTe}_{2}$ and Mo. BaTe and $\mathrm{MoTe}_{2}$ were prepared, respectively, by heating the elements together in silica tubes at $800{ }^{\circ} \mathrm{C}$ during $48 \mathrm{~h}$. Before use, the Mo powder was heated under a hydrogen flow at $1000^{\circ} \mathrm{C}$ for 6 hours. The starting reactants were then pressed into pellets (ca. $5 \mathrm{~g}$ ) and loaded into a molybdenum crucible which was previously outgassed at $1500{ }^{\circ} \mathrm{C}$ for 15 min under a dynamic vacuum of about $10^{-5}$ Torr. The Mo crucible was subsequently sealed under a low argon pressure using an arc-welding system. The sample was heated at a rate of $300^{\circ} \mathrm{C} /$ hour to $1400 \mathrm{C}$, kept at the temperature for 48 hours and then cooled at $100^{\circ} \mathrm{C}$ /hour down to $1100^{\circ} \mathrm{C}$ at which point the furnace was shut down and allowed to cool to room temperature. The resulting product was found to be single-phase on the basis of its Xray powder diffraction pattern carried out on a D8 Bruker Advance diffractometer equipped with a LynxEye detector $\left(\mathrm{CuK} \alpha_{1}\right.$ radiation) and operating at $40 \mathrm{kV}$ and $40 \mathrm{~mA}$. (Figure 1). Crystals were grown by heating a mixture of composition " $\mathrm{Ba}_{2} \mathrm{Mo}_{6} \mathrm{Te}_{6}$ " in a sealed molybdenum crucible at about $1500{ }^{\circ} \mathrm{C}$ for $48 \mathrm{~h}$. The crucible was then cooled at a rate of 100 ${ }^{\circ} \mathrm{C} /$ hour down to $1000{ }^{\circ} \mathrm{C}$, and finally furnace-cooled to room temperature. Crystals thus obtained have the shape of needles with hexagonal cross section.

Single Crystal X-ray Study 
The X-ray diffraction data were collected on a Nonius Kappa CCD diffractometer using graphite-monochromated Mo-K $\alpha$ radiation $(\lambda \square=0.71073 \AA)$ at room temperature. The COLLECT program package [25] was employed to establish the angular scan conditions ( $\varphi$ and $\omega$ scans) used in the data collection. The data set was processed using EvalCCD [26] for the integration procedure. An absorption correction was applied using the description of the crystal faces and the analytical method described by de Meulenaar and Tompa [27]. Analysis of the data revealed that the systematic absence (0001) $1=2 n+1$ was only consistent with the hexagonal space group $\mathrm{P}_{3} / \mathrm{m}$. The structure was solved with the direct methods program SIR97 [28] and refined using SHELXL97 [29] in the P6 $3 / \mathrm{m}$ space group. Refinement of the occupancy factor of the Ba site led to a value of 0.492(3) indicated a half occupation of the cationic site compared to the other hexagonal compounds $\mathrm{M}_{2} \mathrm{Mo}_{6} \mathrm{X}_{6}(\mathrm{M}=\mathrm{Na}, \mathrm{K}, \mathrm{Rb}, \mathrm{Cs}, \mathrm{In}$, $\mathrm{Tl} ; \mathrm{X}=\mathrm{S}, \mathrm{Se}, \mathrm{Te})$. An attempt to refine the structure in the acentric space group $\mathrm{P}_{3}$ was unsuccessful and led to a higher $\mathrm{R}$ factor as well as larger residual electron density peaks. Because of the disordering of the $\mathrm{Ba}$ atom, we made long-exposure rotation photographs along the $\mathrm{a}$ and $\mathrm{c}$ axes on a single crystal of $\mathrm{BaMo}_{6} \mathrm{Te}_{6}$. The latter did not reveal any superlattice reflection. Crystallographic data and X-ray structural analysis for the $\mathrm{BaMo}_{6} \mathrm{Te}_{6}$ compound are summarized in Table 1. The final atomic coordinates, and the equivalent isotropic displacement parameters are gathered in Table 2, and selected interatomic distances are listed in Table 3. Further details of the crystal structure investigation can be obtained from the Fachinformationszentrum Karlsruhe, 76344 Eggenstein-Leopoldshafen, Germany, (fax: (49) 7247-808-666; e-mail: crysdata@fiz.karlsruhe.de) on quoting the depository number CSD- 427614.

\section{Electrical Resistivity Measurements}

The study of the temperature dependence of the electrical resistivity was carried out on a single crystal of $\mathrm{BaMo}_{6} \mathrm{Te}_{6}$ using a conventional ac four-probe method with a current amplitude of $0.1 \mathrm{~mA}$. Contacts were ultrasonically made with molten indium on the single crystal previously characterized on a Nonius Kappa CCD diffractometer. The ohmic behavior and the invariance of the phase were checked during the different measurements at low and room temperature.

Magnetic susceptibility measurements. 
Susceptibility data were collected on cold pressed powder samples (ca. $100 \mathrm{mg}$ ) using a Quantum Design SQUID magnetometer between $4.2 \mathrm{~K}$ and $400 \mathrm{~K}$ and at an applied field of $0.1 \mathrm{~T}$.

\section{RESULTS AND DISCUSSION}

\section{Crystal Structure}

The comparison of the unit cell parameters of the previous compound reported as " $\mathrm{Ba}_{2} \mathrm{Mo}_{6} \mathrm{Te}_{6}$ " $\left(\mathrm{a}=9.41 \AA, \mathrm{c}=4.57 \AA, \mathrm{V}=350 \AA^{3}\right)$ with those of the title compound ( $\mathrm{a}=$ 9.3941 (2) $\AA, c=4.5848$ (1) $\AA, V=350.40(1) \AA^{3}$ ) clearly shows that we are in the presence of the same phase i.e. $\mathrm{BaMo}_{6} \mathrm{Te}_{6}$.

A view of the unit cell of $\mathrm{BaMo}_{6} \mathrm{Te}_{6}$ is given in Figure 1. The structure is composed of infinite chains of trans-face-sharing $\mathrm{Mo}_{6}$ octahedra $\left|\mathrm{Mo}_{6 / 2}\right|_{\infty}^{1}$ capped by Te atoms. These Mo-Te chains run along the $\mathrm{c}$ axis and have crystallographically imposed symmetry -3 . The $\mathrm{Ba}^{2+}$ cations separate the $\left|\mathrm{Mo}_{6 / 2} \mathrm{Te}_{6 / 2}\right|_{\infty}$ chains and are each coordinated to nine Te atoms in a tricapped trigonal-prismatic arrangement with imposed - 6 symmetry. The Mo-Mo distances within and between the $\mathrm{Mo}_{3}$ triangles perpendicular to the $\mathrm{c}$ axis are 2.6602(6) and 2.7593(2) $\AA$, respectively. The latter values are of the same order than those observed in other reduced molybdenum tellurides such as $\mathrm{Mo}_{6} \mathrm{Te}_{8}, \mathrm{Cs}_{2} \mathrm{Mo}_{12} \mathrm{Te}_{14}, \mathrm{Cs}_{3} \mathrm{Mo}_{15} \mathrm{Te}_{17}, \mathrm{Cs}_{4} \mathrm{Mo}_{18} \mathrm{Te}_{20}$ and $\mathrm{Cs}_{6} \mathrm{Mo}_{24} \mathrm{Te}_{26}$ [5] in which the average intratriangle distances range from 2.663 to $2.688 \AA$ and the average intertriangle ones from 2.765 to $2.785 \AA$. However, they differ significantly from those found in $\mathrm{In}_{2} \mathrm{Mo}_{6} \mathrm{Te}_{6}\left(2.639\right.$ and $2.755 \AA$ ) and $\mathrm{Tl}_{2} \mathrm{Mo}_{6} \mathrm{Te}_{6}(2.619$ and $2.746 \AA$ ), the structures of which have been solved from RX powder data [15]. The Mo-Te distances range from 2.8015(4) to 2.8560(2) $\AA$ as usually observed. The Ba-centered tricapped trigonal prisms share triangular faces along [001]. The distance between the $\mathrm{Ba}$ and the Te atoms forming the prism is 3.4799(2) $\AA$ while that with the Te atoms capping the prism is longer, 3.6139 (3) $\AA$. These distances are in agreement with that found in BaTe (3.502 $\mathrm{A})$, for example.

Electrical and Magnetic Properties.

Electrical resistivity measurements were performed on a single-crystal of $\mathrm{BaMo}_{6} \mathrm{Te}_{6}$. The temperature dependence of the electrical resistivity of $\mathrm{BaMo}_{6} \mathrm{Te}_{6}$ measured along the 
chain growth is similar to that reported for the $\mathrm{M}_{2} \mathrm{Mo}_{6} \mathrm{X}_{6}$ compounds $(\mathrm{M}=\mathrm{Na}, \mathrm{K}, \mathrm{Rb}$ and Cs; $\mathrm{X}=\mathrm{Se}, \mathrm{Te}$ ) (Fig. 5). Thus, $\mathrm{BaMo}_{6} \mathrm{Te}_{6}$ is metallic in the temperature range 160-290 $\mathrm{K}$ with a resistivity of about $0.038 \mathrm{~m} \Omega . \mathrm{cm}$ at room temperature and 0.022 a t $160 \mathrm{~K}$. Below $160 \mathrm{~K}$, a semiconductor behaviour is observed since the electrical resistivity increases with decreasing temperature. The activation energy deduced from the linear part of the $1 / \mathrm{T}$ vs. $\log \rho$ plot is $220 \mathrm{~K}$ that is close to that reported for the $\mathrm{Cs}_{2} \mathrm{Mo}_{6} \mathrm{Te}_{6}$ compound (ie $225 \mathrm{~K}$ ) [21].

The temperature dependence of the magnetic susceptibility of $\mathrm{BaMo}_{6} \mathrm{Te}_{6}$ is shown in Figure 5. The susceptibility of the $\mathrm{BaMo}_{6} \mathrm{Te}_{6}$ compound is nearly temperature-independent and weakly diamagnetic in the range $100-300 \mathrm{~K}$ with a value of about $-710^{-8} \mathrm{emu} / \mathrm{g}$ closed to that reported for some $\mathrm{M}_{2} \mathrm{Mo}_{6} \mathrm{X}_{6}$ compounds with $\mathrm{M}$ being an element of the group IA [21]. This behavior is consistent with the absence of localized moments on the Mo atom network. The low-temperature upturn could be attributed to small amounts of paramagnetic impurities often present in the starting reactants. It is interesting to note that no anomaly was observed at the metal-nonmetal transition as previously observed for the $\mathrm{M}_{2} \mathrm{Mo}_{6} \mathrm{X}_{6}$ compounds [21]. This is reminiscent of the well know Anderson localisation that arises from defects [30]. Indeed, unlike the CDW transitions $[31,32]$ that require an opening of gap near the Fermi level and associated changes in the structural and variable temperature magnetization studies, the present compound does not show any reduction in the magnetization value near the metalnonmetal transition. In addition, the broad nature of the transition in the electrical resistivity also supports defect-induced localization of the carriers. A similar observation has also been reported for $\mathrm{KMo}_{4} \mathrm{O}_{6}$ that contains infinite chains of trans-edge shared $\mathrm{Mo}_{6}$ octahedral clusters [33].

\section{CONCLUSION}

In summary, the new compound $\mathrm{BaMo}_{6} \mathrm{Te}_{6}$ has been synthesized by solid state reaction. This compound is isomorphous with the $\mathrm{M}_{2} \mathrm{Mo}_{6} \mathrm{X}_{6}(\mathrm{M}=\mathrm{Na}, \mathrm{K}, \mathrm{Rb}, \mathrm{Cs}, \mathrm{In}, \mathrm{Tl} ; \mathrm{X}=$ $\mathrm{S}, \mathrm{Se}, \mathrm{Te}$ ) compounds and, thus its crystal structure contains infinite chains of trans-facesharing $\mathrm{Mo}_{6}$ octahedra $\left|\mathrm{Mo}_{6 / 2}\right|_{\infty}^{1}$ capped by Te atoms. The $\mathrm{Ba}^{2+}$ cations occupy statically half of the tricapped trigonal prisms formed by the Te atoms between the chains while, in the $\mathrm{M}_{2} \mathrm{Mo}_{6} \mathrm{X}_{6}$ compounds, all the tricapped trigonal prismatic sites are occupied. The temperature dependences of the electrical resistivity and magnetic susceptibility are similar to those observed for the $\mathrm{M}_{2} \mathrm{Mo}_{6} \mathrm{X}_{6}$ compounds with $\mathrm{M}$ being an element of the group IA. In 
particular, the broad metal-nonmetal transition around $160 \mathrm{~K}$ results probably from an Anderson type localization due to the absence of anomaly in the magnetization curve. Finally, it would be interesting to study the thermoelectric properties of $\mathrm{BaMo}_{6} \mathrm{Te}_{6}$ and $\mathrm{M}_{2} \mathrm{Mo}_{6} \mathrm{X}_{6}(\mathrm{M}$ $=\mathrm{Na}, \mathrm{K}, \mathrm{Rb}, \mathrm{Cs} ; \mathrm{X}=\mathrm{S}, \mathrm{Se}, \mathrm{Te})$. Indeed, recent works on the finite chain cluster compounds $\mathrm{Ag}_{x} \mathrm{Mo}_{9} \mathrm{Se}_{11}(3.4 \leq x \leq 3.9)$ and $\mathrm{Ag}_{3} \mathrm{In}_{2} \mathrm{Mo}_{15} \mathrm{Se}_{19}$ containing Mog clusters [34-36] have shown that Mo cluster chalcogenides are good candidates for thermoelectricity.

\section{References}

[1] R. Chevrel, M. Sergent, in: Ø. Fischer, M.B. Maple (Eds), Superconducting in Ternary Compounds, part I., Springer Verlag: Berlin, Heidelberg, New York, 1982, pp. 25-86.

[2] P. Gougeon, J. Padiou, J. Y. Le Marouille, M. Potel, M. Sergent, J. Solid State Chem. 51 (1984) 218.

[3] S. Picard, J.-F. Halet, P. Gougeon, M. Potel, Inorg. Chem. 38 (1999) 4422.

[4] P. Gougeon, M. Potel, J. Padiou, M. Sergent, Mat. Res. Bull. 22 (1988) 1087.

[5] C. Thomas, S. Picard, R. Gautier, P. Gougeon, M. Potel, J. Alloys Comp. 262-263 (1997) 305.

[6] R. Gautier, S. Picard, P. Gougeon, M. Potel, Mat. Res. Bull. 34 (1999) 93-101.

[7] P. Gougeon, M. Potel, M. Sergent, Acta Cryst. C45 (1989) 182.

[8] P. Gougeon, M. Potel, M. Sergent, Acta Cryst. C45 (1989) 1413.

[9] P. Gougeon, M. Potel, J. Padiou, M. Sergent, Mat. Res. Bull. 23 (1988) 453.

[10] P. Gougeon, M. Potel, M. Sergent, Acta Cryst. C46 (1990) 2284.

[11] S. Picard P. Gougeon, M. Potel, Acta Cryst. C53 (1997) 1519.

[12] S. Picard, M. Potel, P. Gougeon, Angew. Chem. 38 (1999) 2023.

[13] M. Potel, R. Chevrel, M. Sergent, J.C. Armici, M. Decroux, Ø. Fischer J. Solid State Chem., 35 (1980) 286.

[14] W. Hönle,H. G. von Schnering; A. Lipka, K. Yvon, J. Less Com. Metals 71 (1980) 135.

[15] P. Gougeon, M. Potel, J. Padiou, M. Sergent, J. Solid State Chem. 68 (1987) 137.

[16] R. Brusetti, O. Laborde, A. Sulpice, R. Calemczuk, M. Potel, P. Gougeon, Phys. Rev. B 52 (1995) 4481.

[17] J. C. Armici, M. Decroux, Ø. Fischer, M. Potel, R. Chevrel, M. Sergent, Solid State Comm. 33 (1980) 607.

[18] R. Lepetit, P. Monceau, M. Potel, P. Gougeon, M. Sergent, J. Low Temp. Phys. 56 (1984) 219. 
[19] R. Brusetti, P. Monceau, M. Potel, P. Gougeon, M. Sergent, Solid State Commun. 66 (1988) 181.

[20] R. Brusetti, A. Briggs, O. Laborde, M. Potel, P. Gougeon, Phys. Rev. B 49 (1994) 8931.

[21] J. M. Tarascon, F. J. DiSalvo, J. V. Waszczak, Solid State Comm. 52 (1984) 227.

[22] A.P. Petrović, R. Lortz, G. Santi, M. Decroux, H. Monnard, $\varnothing$. Fischer, L. Boeri, O.K. Andersen, J. Kortus, D. Salloum, P. Gougeon, M. Potel, Phys. Rev. B 82 (2010) 8931.

[23] R. Chevrel, P. Gougeon, M. Potel, M. Sergent, J. Solid State Chem. 57 (1985) 25.

[24] T. Hughbanks, R. Hoffmann, Inorg. Chem. 21 (1982) 3578.

[25] Nonius BV, COLLECT, Data Collection Software, Nonius BV, 1999.

[26] A. J. M. Duisenberg, Reflections on area detectors, Ph.D. Thesis, Utrecht, 1998.

[27] J. de Meulenaar, H. Tompa, Acta Crystallogr., Sect. A: Found. Crystallogr. 19 (1965) 1014.

[28] A. Altomare, M. C. Burla, M. Camalli, G. L. Cascarano, C. Giacovazzo, A. Guagliardi, A. G. G. Moliterni, G. Polidori, R. Spagna, J. Appl. Cryst. 32 (1999) 115.

[29] G. M. Sheldrick, SHELXL97, Program for the Refinement of Crystal Structures, University of Göttingen, Germany, 1997.

[30] P. W. Anderson, Phys. Rev. 109 (1958) 1492.

[31] R. E. Peierls, Quantum Theory of Solids, Oxford University, New York/London, 1955.

[32] G. Grüner, Reviews of Modern Physics 60 (1988) 1129.

[33] K. V. Ramanujachary, M. Greenblatt, E. B. Jones, W. H. McCarroll, J. Solid State Chem. 102 (1993) 69.

[34] T. Zhou, B. Lenoir, M. Colin, A. Dauscher, R. Al Rahal Al Orabi, P. Gall, P. Gougeon, M. Potel, E. Guilmeau, Appl. Phys. Lett. 98 (2011) 162106.

[35] T. Zhou, M. Colin, C. Candolfi, C. Boulanger, A. Dauscher, E. Santava, J. Hejtmanek, P. Baranek, R. Al Rahal Al Orabi, M. Potel, B. Fontaine, P. Gougeon, R. Gautier, B. Lenoir, Chem. Mater. (2014) in press.

[36] P. Gougeon, P. Gall, R. Al Rahal Al Orabi, B. Fontaine, R. Gautier, M. Potel, T. Zhou, B. Lenoir, M. Colin, C. Candolfi, A. Dauscher, Chem. Mater. 24 (2012) 2899. 


\section{Figure Captions}

Figure 1. Observed (crossed), calculated (black line) and difference profiles for the refinement of $\mathrm{BaMo}_{6} \mathrm{Te}_{6}$ in profile-matching mode $(\lambda=1.5406 \AA)$.

Figure 2. The crystal structure of $\mathrm{BaMo}_{6} \mathrm{Te}_{6}$ as viewed down the $\mathrm{c}$ axis, parallel to the direction of the $\mathrm{Mo}_{6 / 2}$ chain growth. Ellipsoids are drawn at the $97 \%$ probability level.

Figure 3. The crystal structure of $\mathrm{BaMo}_{6} \mathrm{Te}_{6}$ as viewed perpendicularly to the $\mathrm{Mo}_{6 / 2}$ chain growth (ellipsoids at the $97 \%$ probability level).

Figure 4. Tellurium environment for the Ba atom (ellipsoids at the $97 \%$ probability level).

Figure 5. Temperature dependence of the resistivity for $\mathrm{BaMo}_{6} \mathrm{Te}_{6}$. The inset shows the Arrhenius plots.

Figure 6. Magnetic susceptibility of $\mathrm{BaMo}_{6} \mathrm{Te}_{6}$ as a function of temperature. Data were taken under an applied field of $0.1 \mathrm{~T}$. 
Table 1. Crystal data and structure refinements of $\mathrm{BaMo}_{6} \mathrm{Te}_{6}$

\begin{tabular}{|l|l|}
\hline Empirical formula & $\mathrm{BaMo}_{6} \mathrm{Te}_{6}$ \\
\hline Formula weight $\left(\mathrm{gmol}^{-1}\right)$ & 1478.58 \\
\hline Crystal system, space group & hexagonal, $\mathrm{P}_{3} / \mathrm{m}$ \\
\hline Unit cell dimensions $(\AA, \mathrm{deg})$ & $a=9.3941(2), c=4.5848(1)$ \\
\hline Volume $\left(\AA^{3}\right)$ & $350.40(1)$ \\
\hline$Z$, Calculated density $\left(\mathrm{g} / \mathrm{cm}^{3}\right)$ & $1,7.007$ \\
\hline Absorption coefficient $\left(\mathrm{mm}^{-1}\right)$ & 20.151 \\
\hline Crystal color and habit & $\mathrm{Black}$, needle like \\
\hline Crystal size (mm $\left.{ }^{3}\right)$ & $0.152 \times 0.063 \times 0.057$ \\
\hline Theta range for data collection $(\mathrm{deg})$ & $2.50-32$ \\
\hline Limiting indices & $-14 \leq h \leq 14,-14 \leq k \leq 14,-5 \leq l \leq 6$ \\
\hline Reflections collected/unique & $8209 / 452$ \\
\hline$R$ (int) & 0.0444 \\
\hline Absorption correction & Analytical \\
\hline Max./min. transmission & $0.4142 / 0.1328$ \\
\hline Data/restraints/parameters & $3903 / 0 / 101$ \\
\hline Goodness-of-fit on $F^{2}$ & 1.081 \\
\hline$R$ indices $[I>2 \sigma(I)]$ & $\mathrm{R} 1=0.0208, \mathrm{wR} 2=0.0539$ \\
\hline Extinction coefficient & $0.00418(11)$ \\
\hline Largest diff. peak and hole $\left(\mathrm{e} \AA^{-3}\right)$ & 1.437 and -1.177 \\
\hline & \\
\hline
\end{tabular}


Table 2. Atomic coordinates and equivalent isotropic displacement parameters $\left(\AA^{2}\right)$ for the compound $\mathrm{BaMo}_{6} \mathrm{Te}_{6}$.

\begin{tabular}{|l|c|l|l|l|l|l|}
\hline Atom & $\begin{array}{l}\text { Wyckoff } \\
\text { position }\end{array}$ & $\mathrm{x}$ & $\mathrm{y}$ & $\mathrm{z}$ & $\mathrm{Ueq}$ & s.o.f \\
\hline $\mathrm{Mo}$ & $6 \mathrm{~h}$ & $-0.14384(4)$ & $0.03396(4)$ & 0.7500 & $0.00504(14)$ & 1 \\
\hline $\mathrm{Te}$ & $6 \mathrm{~h}$ & $0.07032(3)$ & $0.37457(3)$ & 0.7500 & $0.00659(13)$ & 1 \\
\hline $\mathrm{Ba}$ & $2 \mathrm{c}$ & 0.3333 & 0.6667 & 0.2500 & $0.0075(3)$ & $0.492(3)$ \\
\hline
\end{tabular}


Table 3. Selected Interatomic Distances $(\AA)$ for $\mathrm{BaMo}_{6} \mathrm{Te}_{6}$.

\begin{tabular}{|l|l|l|l|}
\hline Mo-Mo (X2) & $2.6602(6)$ & Ba-Te (X6) & $3.4799(2)$ \\
\hline Mo-Mo (X4) & $2.7593(2)$ & Ba-Te (X3) & $3.6139(3)$ \\
\hline Mo-Te & $2.8015(4)$ & & \\
\hline Mo-Te & $2.8117(4)$ & & \\
\hline Mo-Te (X2) & $2.8560(2)$ & & \\
\hline
\end{tabular}




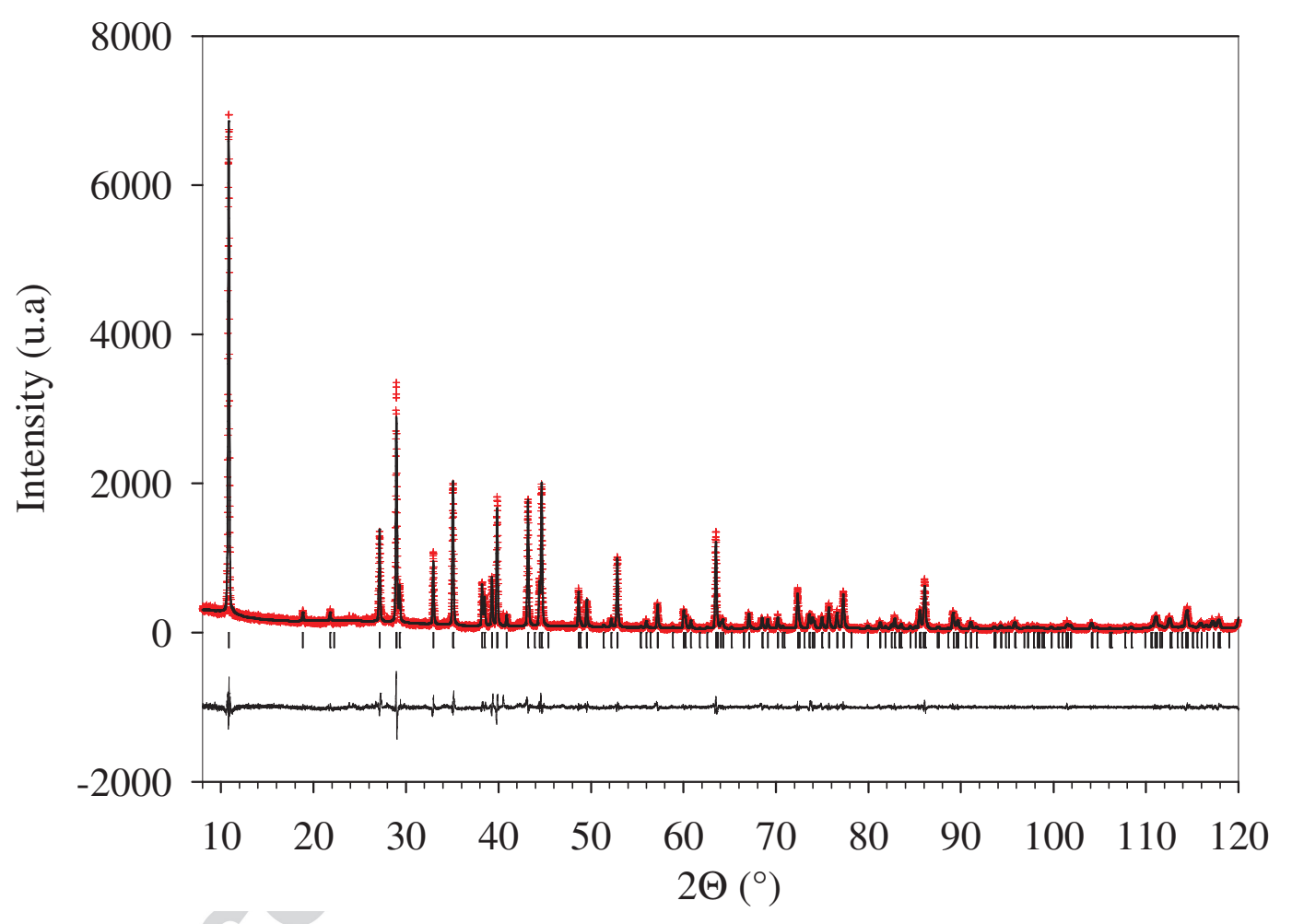

Figure 1. Observed (crossed), calculated (black line) and difference profiles for the refinement of $\mathrm{BaMo}_{6} \mathrm{Te}_{6}$ in profile-matching mode $(\lambda=1.5406 \AA)$. 


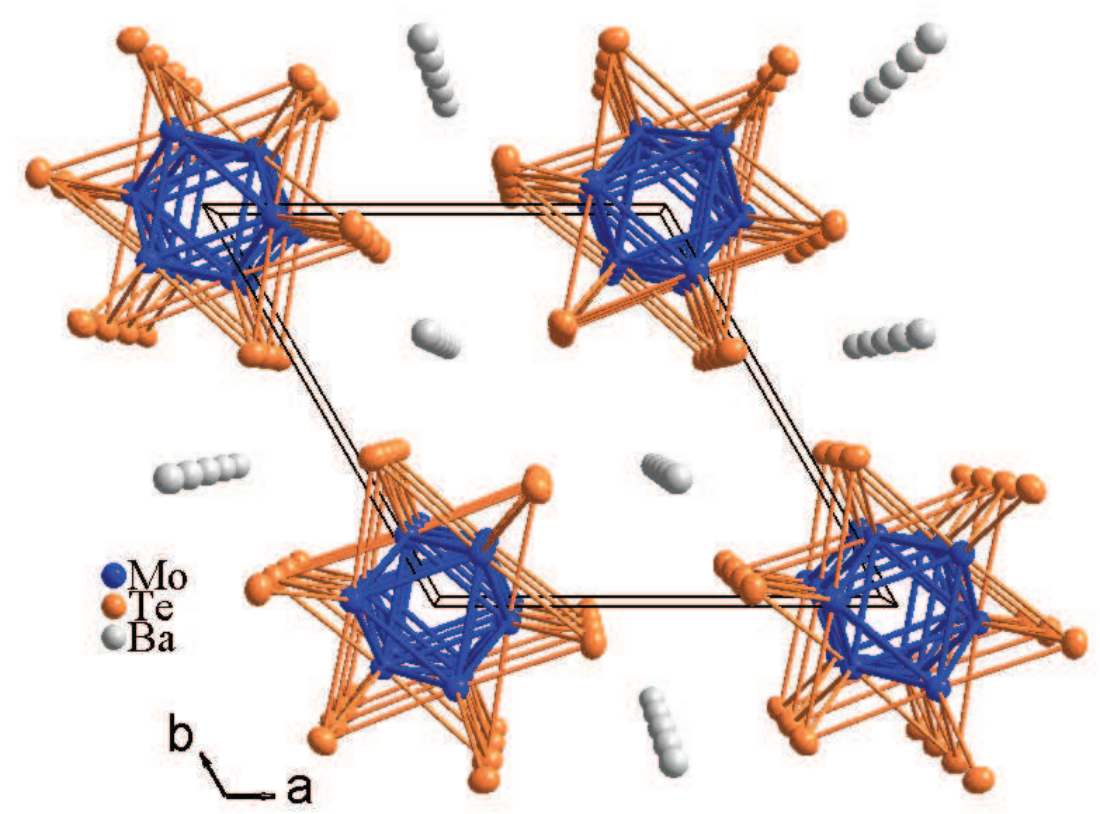

Figure 2. The crystal structure of $\mathrm{BaMo}_{6} \mathrm{Te}_{6}$ as viewed down the $\mathrm{c}$ axis, parallel to the direction of the $\mathrm{Mo}_{6 / 2}$ chain growth. Ellipsoids are drawn at the $97 \%$ probability level. 


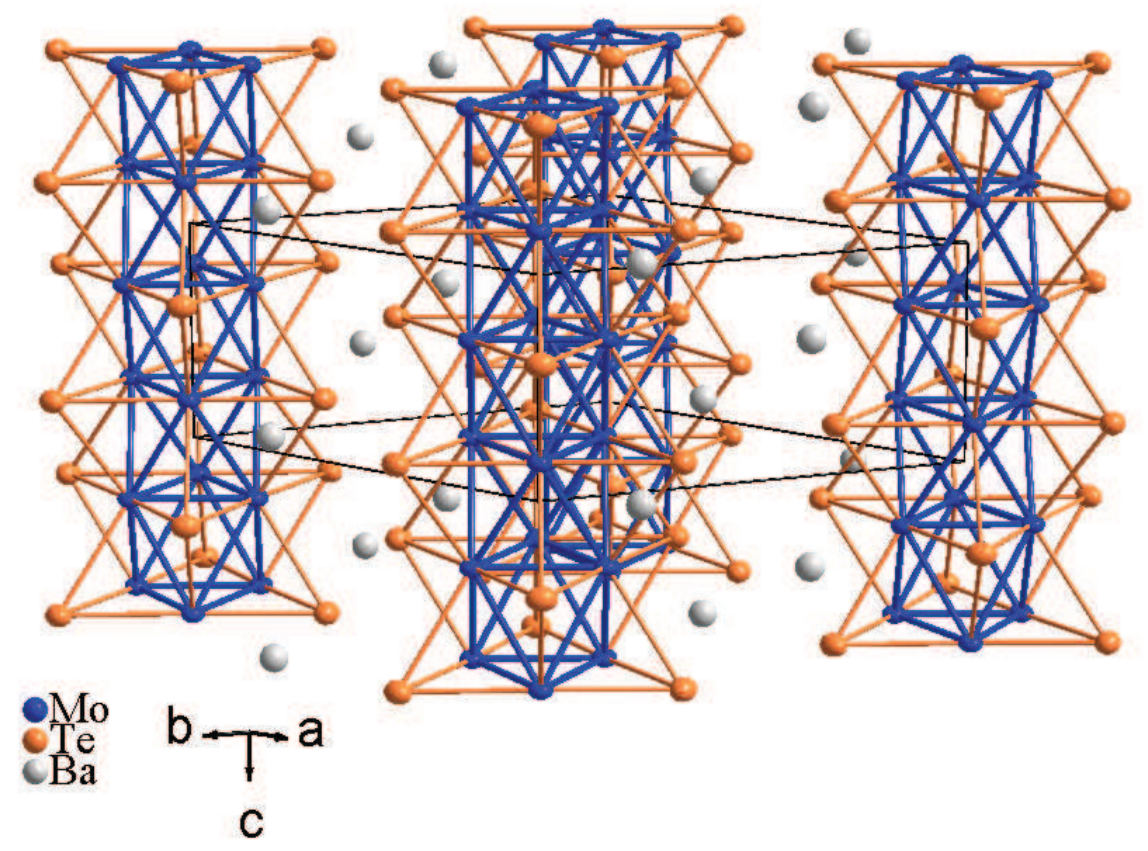

Figure 3. The crystal structure of $\mathrm{BaMo}_{6} \mathrm{Te}_{6}$ as viewed perpendicularly to the $\mathrm{Mo}_{6 / 2}$ chain growth (ellipsoids at the $97 \%$ probability level). 


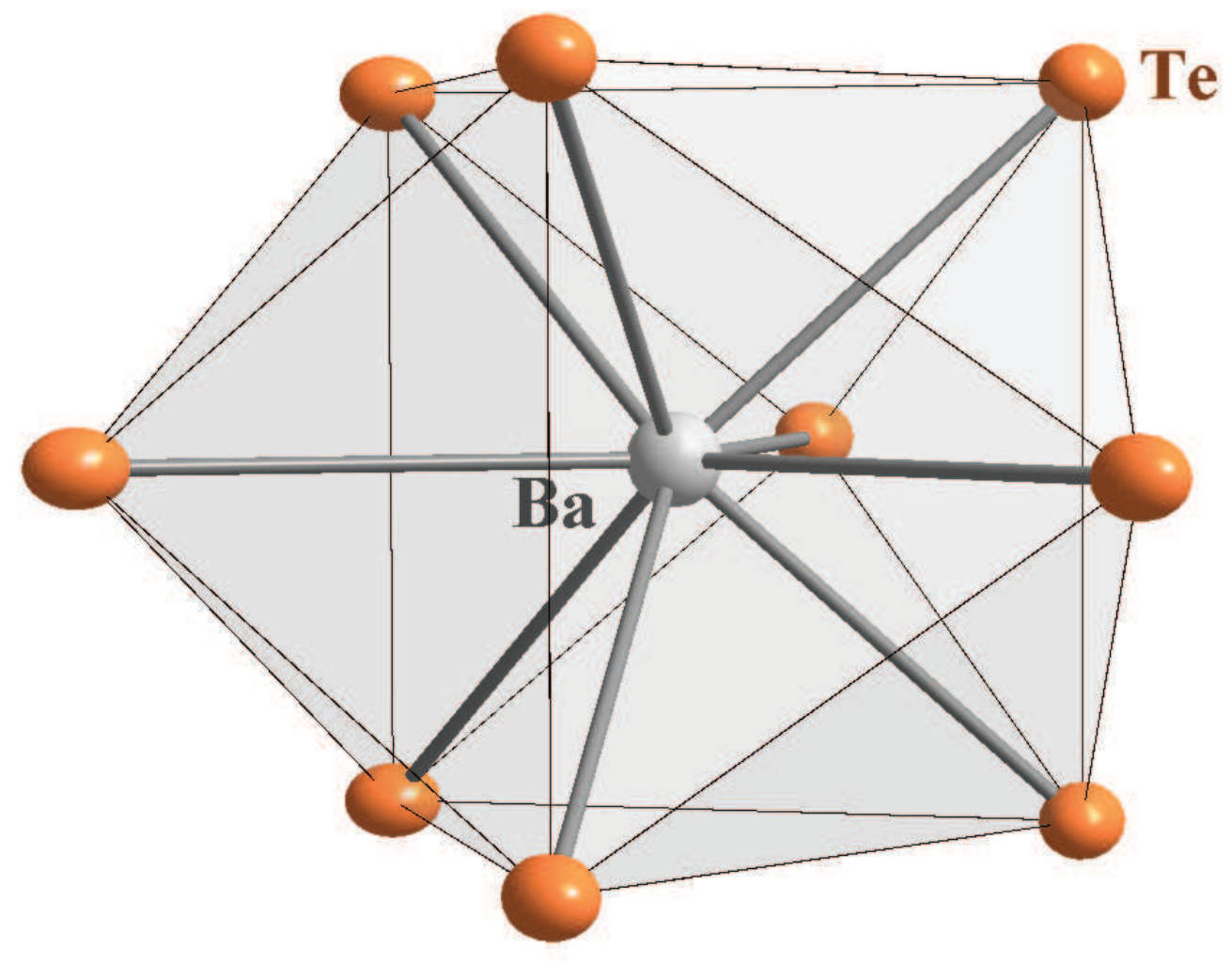

Figure 4. Tellurium environment for the Ba atom (ellipsoids at the $97 \%$ probability level). 


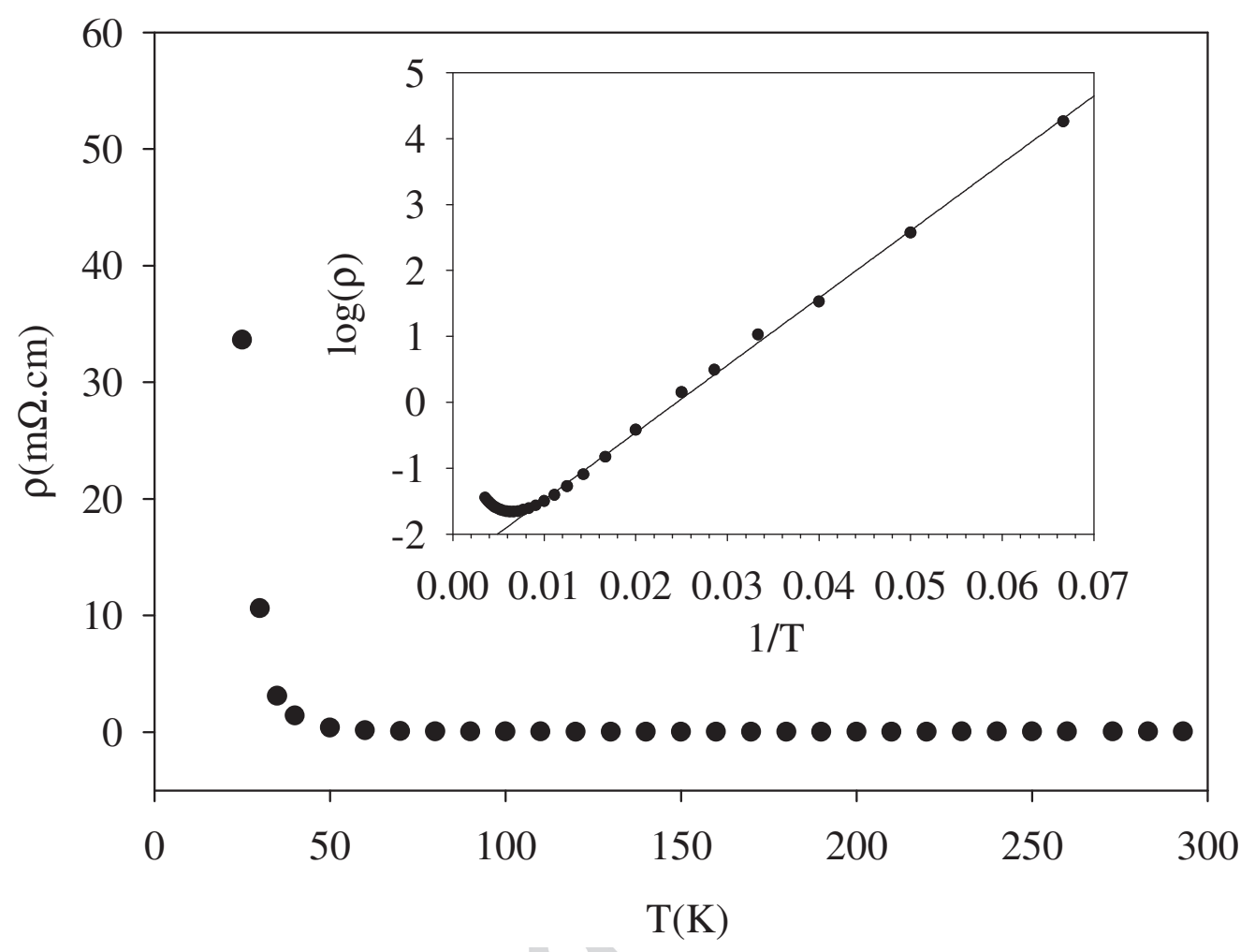

Figure 5. Temperature dependence of the resistivity for $\mathrm{BaMo}_{6} \mathrm{Te}_{6}$. The inset shows the Arrhenius plots. 


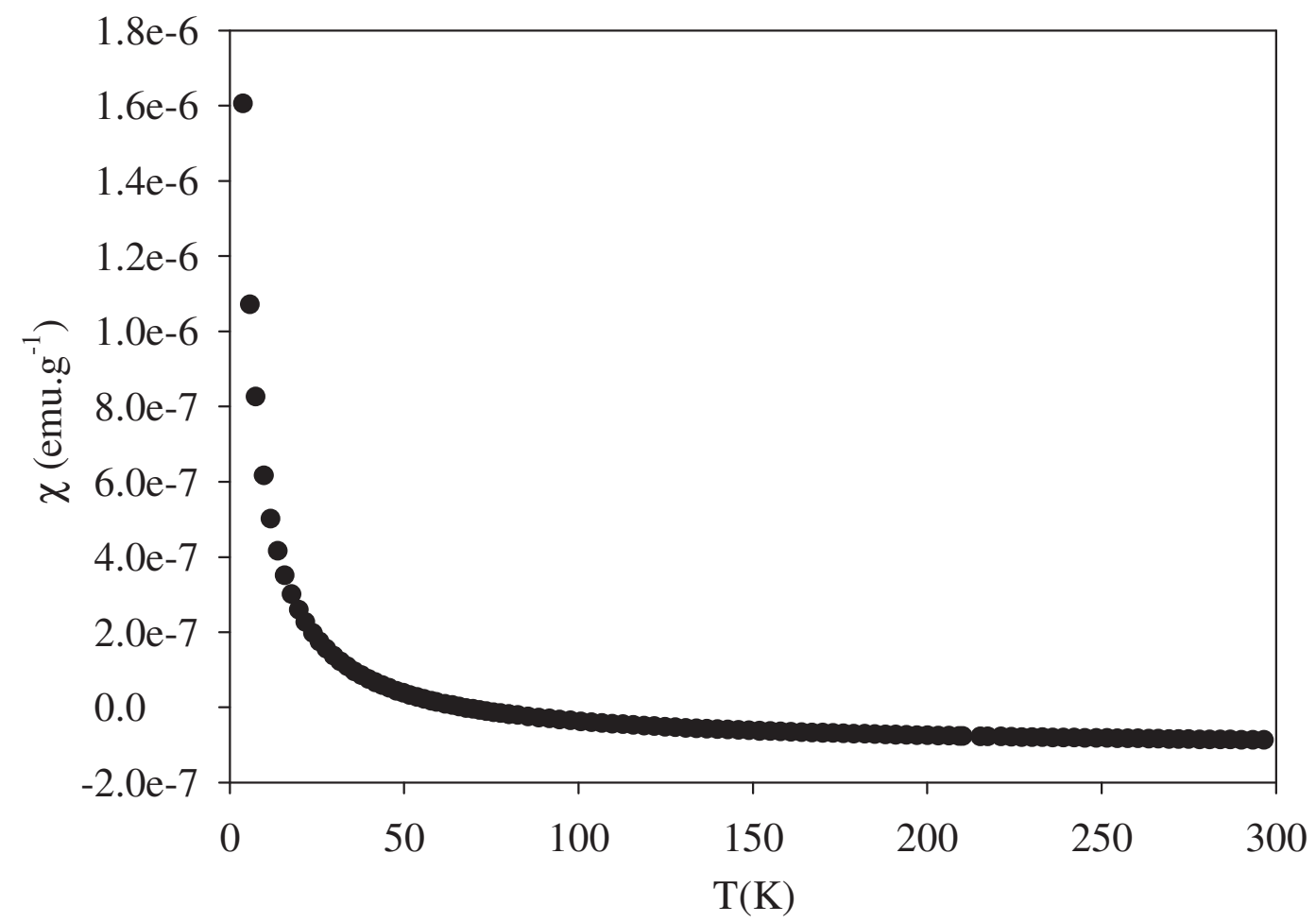

Figure 6. Magnetic susceptibility of $\mathrm{BaMo}_{6} \mathrm{Te}_{6}$ as a function of temperature. Data were taken under an applied field of $0.1 \mathrm{~T}$. 
Synthesis, crystal structure, and electrical and magnetic properties of BaMo $_{6} \mathrm{Te}_{6}$ : a novel reduced molybdenum telluride containing infinite chains of trans-face shared $\mathrm{Mo}_{6}$ octahedra

Philippe Gall, Thierry Guizouarn, Michel Potel and Patrick Gougeon*

Laboratoire de Chimie du Solide et Inorganique Moléculaire, UMR CNRS 6226 - INSA,

Université de Rennes 1, Avenue du Général Leclerc, 35042 Rennes-Cedex, France.

We present here the synthesis, the crystal structure, and the electrical and magnetic properties of the new compound $\mathrm{BaMo}_{6} \mathrm{Te}_{6}$ containing infinite chains of trans-face shared $\mathrm{Mo}_{6}$ octahedra

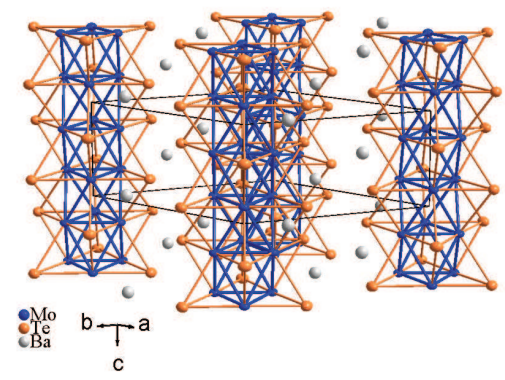




\section{Highlights}

. $\mathrm{BaMo}_{6} \mathrm{Te}_{6}$ contains infinite chains of trans-face-sharing $\mathrm{Mo}_{6}$ octahedra $\left|\mathrm{Mo}_{6 / 2}\right|_{\infty}$.

. Synthesis by solid state reaction.

. Single-crystal X-ray study.

. Continuous metal-nonmetal transition.

. Anderson localization. 